\title{
Human land-use, forest dynamics and tree growth at the treeline in the Western Italian Alps
}

\author{
Renzo MotTA $^{\mathrm{a} *}$, Mariano Morales $^{\mathrm{b}}$, Paola NOLA $^{\mathrm{c}}$ \\ a Dep. Agroselviter University of Turin, Via Leonardo da Vinci 44, 10095 Grugliasco (TO), Italy \\ ${ }^{\mathrm{b}}$ Dep. de Dendrocronología e Historia Ambiental, IANIGLA-CRICYT, CC330, CP 5500, Mendoza, Argentina \\ ${ }^{\mathrm{c}}$ Dep. Ecoter University of Pavia, Via S. Epifanio 14, 27100 Pavia, Italy
}

(Received 5 October 2005; accepted 9 March 2006)

\begin{abstract}
Three plots were sampled along an altitudinal gradient in the upper Susa Valley (Piedmont, Italy) on a northeastern slope from 1800 to $2300 \mathrm{~m}$ a.s.l. In order to reconstruct recent dynamics at this altitudinal range various techniques were used. Dendroecological methods were used to reconstruct the age structures of tree populations. Growth dynamics were investigated both by observing Basal Area Increment (BAI) in old and dominant trees and by comparing the BAIs within a given cambial age class in different time periods. Historical documents were analyzed as an independent data source to explain changes in establishment rate. As far as the tree establishment at the forestline and at the treeline is concerned we observed three distinct periods: during the first one (1850-1930) larch establishment was reduced or prevented because of heavy grazing and the stone pine establishment was almost null because of the grazing and of the human anthropogenic removal. During the second one (1930-1960) the past heavy grazing followed by periods of moderate grazing favored the larch establishment; stone pine establishment was still prevented both by grazing and by anthropogenic removal. Finally the third period (1960-present) has been the period of massive stone pine regeneration. The growth rates of stone pine and larch have increased in the last decades: individuals in the 100-, 150- and 200-year age classes grow more rapidly in present times as compared to the previous two centuries. In the same time younger trees (1-50 years old) showed a decline in growth because the current stands are denser and the young and suppressed trees have worse growth conditions respect the previous open stands. An analysis of all the data taken together in the present study argues in favor of the fact that the tree establishment, and more in general the forest dynamic, has been mainly controlled by human land-use and that the tree growth has been mainly climatically controlled.
\end{abstract}

dendroecology / Larix decidua / Pinus cembra / tree-rings / basal area increment (BAI) / herbivory

Résumé - Histoire de l'occupation du sol, et dynamique forestière à la limite supérieure des arbres dans la vallée de Suse (Piémont, Italie). Afin de reconstruire la dynamique récente de l'étage subalpin, la présente étude a mis en œuvre plusieurs techniques. Des méthodes dendrochronologiques ont permis de reconstruire la structure d'âges des populations d'arbres. La croissance a été étudiée à la fois par l'observation de l'accroissement en surface terrière des vieux arbres dominants et en comparant les accroissements en surface terrière des classes d'arbres avec la même classe d'âge cambial à différentes périodes de temps. De plus, des documents d'archives ont été étudiés. On a observé trois phases distinctes d'établissement des arbres : la première (1850-1930) durant laquelle il n'y a pas d'établissement d'arbre à cause de la forte pression du pâturage, la deuxième (1930-1960) durant laquelle il y a établissement de mélèzes, car la pression du pâturage diminue et la troisième (1960-aujourd'hui) avec établissement de pins cembro où la pression du pâturage continue de diminuer et où le pin cembro n'est plus arraché systématiquement par l'homme. L'accroissement des arbres a montré une augmentation dans les dernières décennies parmi les arbres dominants et co-dominants tandis qu'une diminution de l'accroissement à été observée parmi les plus jeunes. Le pastoralisme semble être le facteur principal influençant la dynamique passée et récente des peuplements forestiers d'altitude, alors que les changements climatiques pourraient être responsables d'une augmentation de la vitesse de croissance des arbres.

dendroécologie / Larix decidua / Pinus cembra / cernes / accroissement en surface terrière / pâturage du bétail

\section{INTRODUCTION}

Within the last century, there has been clear evidence that trees have greatly encroached upon open areas located near the treeline. This phenomenon has been observed in many mountain ranges in the northern $[13,30,46,52,53,55]$ and southern hemisphere [10,62]. A smaller number of studies, however, have also shown that these limits are relatively stable [25]. In the same time tree-growth increments at the tree-

\footnotetext{
*Corresponding author: renzo.motta@unito.it
}

line have been observed in many mountains around the world $[20,27,44,45,48]$.

The hypothesis attempting to explain these processes are focused on changes in climate, $\mathrm{CO}_{2}$ concentration, fire regimes and, in the mountains where humans have social or economical interests, land-use change and, particularly, the grazing of domestic animals $[6,7,15,34,57,65]$.

The last one is the case of the western Italian Alps where human disturbances intensity peaked towards the middle of the nineteenth century [31]. Indeed, this was the time of maximum population density in the valleys with consequent exploitation of all the resources and space available. Beginning 
in the second half of the nineteenth century, human influence on the subalpine forests and on the Western Italian Alps treelines began to diminish due to emigration and depopulation tendencies in most of these valleys. In the last century the economy and social structure of alpine valleys has underwent radical changes: tourism has now practically replaced agriculture as the principal source of income. Thus forest expansion over the last century has taken place under extremely favorable conditions due to both the atmospheric warming together with a particularly auspicious period due to an abrupt decrease in human activities at this altitudinal level.

The present study was conducted in the Upper Susa Valley (Western Italian Alps), in order to reconstruct recent forest dynamic at the subalpine, forestline and treeline levels using natural and documentary archives. The main aims were: (a) to characterize forest structure and dynamics at three different altitudes; (b) to study the relationship between the primary human disturbance factor, grazing, and the establishment of trees at the forestline and treeline; and (c) to determine, by means of dendroecological analysis, the growth trends of the two dominant species i.e. the larch (Larix decidua Mill.) and the Swiss stone pine (Pinus cembra L.)

\section{MATERIAL AND METHODS}

\subsection{The study area}

The study area is located in the Upper Susa Valley on a northeastern slope from 1800 to $2300 \mathrm{~m}$ a.s.l. The forests are dominated by larch and stone pine with some sparse mountain pine (Pinus uncinata Mill.). The forest type is "Larch and stone pine with Calamagrostis villosa" sub-type with Festuca paniculata. Total rainfall is $881 \mathrm{~mm} \mathrm{yr}^{-1}$ with January being the driest month and May the wettest.

\subsection{Land-use history}

The studies carried out were supplemented by interviews with local foresters, an analysis of Forest Management plans (1966 up to the present), and chronicles, diaries, cultural histories, land surveys, maps, plot measurements, weather observations supplied by the Historical Archives of the Municipality of Cesana Torinese.

\subsection{Permanent plots}

Three plots along an altitudinal gradient were selected: SF inside the subalpine forest, $200 \mathrm{~m}$ below the forestline; FL at the forestline (forest was defined as having a cover of at least $30 \%$ and a surface area of at least $500 \mathrm{~m}^{2}$ ) and TL at the treeline (line connecting the outermost erect trees with a height of more than $2 \mathrm{~m}$ ). The plots were selected to have a uniform slope with a regular topography in order to reduce the microsite influence on the tree growth [32]. The SF plot was $10000 \mathrm{~m}^{2}$ while the other two were $2000 \mathrm{~m}^{2}(20 \times 100 \mathrm{~m}$ with the long side along the contour lines). In each plot all the trees (diameter at breast height $>7.5 \mathrm{~cm}$ ) and saplings (height $>10 \mathrm{~cm}$ and $\mathrm{dbh}<7.5 \mathrm{~cm}$ ) were identified and permanently marked; dbh (only for individuals higher than $1.3 \mathrm{~m}$ ), height and topographic coordinates were measured.

\subsection{Dendroecological analysis}

\subsubsection{The increment cores}

An increment core was taken upslope at a height of $50 \mathrm{~cm}$ from each tree with $\mathrm{dbh}>7.5 \mathrm{~cm}$ (referred to as C50). Additional cores (referred to as $\mathrm{C} 130$ ) were taken at a height of $130 \mathrm{~cm}$ from 16 dominant trees distributed throughout the entire study area for both species (larch and stone pine). In the laboratory, all the cores were fixed to wooden supports and sanded with successively finer grades of sandpaper until optimal surface resolution allowed annual rings to be measured. The rings were measured with $0.01 \mathrm{~mm}$ accuracy under a binocular microscope.

\subsubsection{Cross-dating and chronologies}

The program COFECHA [26] was used to detect errors, absents and false rings. Data from $\mathrm{C} 130$ were used to build a reference chronology for each species.

Data from C50 were used to obtain plot chronologies: 3 for larch (related to SF, FL, and TL), and 1 for stone pine (SF). These data were standardized using the ARSTAN program [9] to eliminate the ageing growth trend and minimize the non-common growth variations of all trees [16]. To assess the temporal variability in the strength of the common signal, we calculated a running series of average correlations (Rbar) for each plot chronology [5], using a 40-year window with an overlap of 30 years between adjacent windows.

To better distinguish environmental signals in the chronologies, we calculated the correlation coefficient between the SF and TL larch plot chronologies, which represent the two extreme ends of the scale both in terms of altitude and of grazing intensity. In this case we used a 20-year window with an overlap of 19 years between adjacent windows. The value of the correlation was assigned to the median year of the window.

\subsubsection{Age structure}

Age structure was calculated using data from C50. In order to take into account the number of years the trees had taken to attain coring height $(50 \mathrm{~cm}), 12$ and 19 years were added for the larch and the stone pine respectively to the number of years counted or estimated at the sampling height . This procedure is based on the assumption that the harvested saplings grew at the same rate as the initial growth rate of the mature trees from which the cores were obtained [59]. Since the procedures utilized for age estimation can introduce errors into subsequent analyses, age structure was constructed for 10-year classes to account for these errors [41].

\subsubsection{Tree growth and basal area increments}

To estimate the net productivity of a tree, the raw ring widths were converted into basal area increments (BAI) $[4,41,54,63]$. BAIs were calculated by means of the FISURF software [23]. BAIs from C130 were used to construct a mean BAI chronology for each species for the analysis of growth trends in dominant trees, while BAIs obtained from C50 (BAI50) were used in the analysis of growth trends within age-stratified data. 
Table I. Main characteristics and occurrence of trees and saplings (height $>10 \mathrm{~cm}$ and diameter at breast height $<7.5 \mathrm{~cm}$ ) in the three plots.

\begin{tabular}{|c|c|c|c|c|c|c|c|c|}
\hline \multirow{2}{*}{ Plots } & \multirow{2}{*}{ Elevation (m) } & \multirow{2}{*}{ Basal area total $\left(\mathrm{m}^{2} \mathrm{ha}^{-1}\right)$} & \multicolumn{3}{|c|}{ Trees $\left(\mathrm{nha}^{-1}\right)$} & \multicolumn{3}{|c|}{ Saplings $\left(\mathrm{n} \mathrm{ha}^{-1}\right)$} \\
\hline & & & Total & Pinus cembra & Larix decidua & Total & Pinus cembra & Larix decidua \\
\hline Subalpine forest (SF) & 2010 & 27.2 & 234 & 130 & 104 & 702 & 635 & 67 \\
\hline Forest line (FL) & 2270 & 10.9 & 190 & 20 & 170 & 835 & 565 & 270 \\
\hline Tree line (TL) & 2300 & 4.1 & 95 & 5 & 90 & 160 & 110 & 50 \\
\hline
\end{tabular}

\subsubsection{Growth trends in dominant trees}

A low pass filter [16] was applied to the mean BAI chronology for the larch and the stone pine in order to highlight the low frequency signal. In order to avoid bias in the results, no indexation process was applied to the data [27].

\subsubsection{Growth trends within age-stratified data}

Radial growth was analyzed within age classes in the SF plot to check whether there were any size differences between the BAIs related to rings produced by trees of the same cambial age in different periods $[3,4]$. BAI50 were divided into age classes so that only data derived from rings within a specific age range are averaged in succession [4]. Only the series derived from complete cores or from cores where the innermost rings allowed the estimation of pith location and cambial age were included in the analysis [40].

\section{RESULTS}

\subsection{Land-use history}

The documentary and archival data available are discontinuous but fundamental in order to draw the general picture of the recent land-use change in the municipality of Cesana T. Cattle, sheep and goat grazing have been going on for centuries. Grazing intensity has peaked at the middle of the 19th century and has decreased over last century. A first sharp reduction in grazing intensity took place in the first decades of the 20th century and a second one after the second world war. The highest numbers of inhabitants (3460) were in the middle of the 19th century. Afterwards, the number of inhabitants began to decrease gradually up to 1961 when the lowest population statistic was recorded (937), almost $70 \%$ less than the maximum value recorded 140 years earlier. Until the 1950's, the number of inhabitants was well correlated with the number of resident domestic animals; following that point however, the employment underwent a shift from agriculturally-based to tourism.

In 18th and 19th century pasturing animals were predominantly sheep and goat. Goat grazing was banned in 1925 and during the last decades cattle has become more and more important.

The use of forest was much more intensive in the 18th and 19th century than today. Larch was favoured by humans for livestock herding purposes because it has a light canopy which permits the growth of suitable foraging ground cover. Until the 1960 s, leasing contracts for the best pastures in the municipality of Cesana T. contained a clause obliging the holder to maintain the pasture by removing any stone pine seedling established.

The cuts carried out in the study area in the last two centuries have generally been cuts for firewood (the inhabitants had, and still have, the right of yearly certain amount of firewood for each family) and a few extraordinary cuts (1869, $1874,1878,1896,1898,1924)$ to answer the needs of the municipality [39].

The institution of the "Consorzio Forestale Alta Valle Susa" and more stringent regulations on the separation of grazing of domestic ungulates and forest land in the second half of the 20th century saw a general decrease in grazing and the application of a close-to-nature silviculture in the whole valley [12]. In the last decades wild ungulates increased in number and expanded their range [36].

\subsection{Forest dynamic}

In the subalpine forest, the number of stone pine individuals was similar to that of larch, but at the forestline and treeline, the number of stone pine decreased drastically. Conversely, the larch dominates in these two environments, representing more than $80 \%$ of total trees. Despite the dominance of larch in the three stands, the number of stone pine saplings was always greater than those of larch (Tab. I). The present incidence of ungulate damage was negligible $(<5 \%$ individuals browsed of both species in each plot).

Over the past 200 years, the subalpine forest has seen a regeneration more or less continuous over time. The larch dominated in the 18th century while the stone pine began to overtake it in the 19th century, until it became almost completely and exclusively dominant in the 20th (Fig. 1; Tab. I).

At the forestline, the regeneration of the present populations began about 160 years ago with an increase in establishments starting from approximately 1920 . Here the larch has been the dominant species throughout the entire time period with only sporadic stone pine individuals appearing. The situation at the treeline shows the establishment of a few sporadic individuals towards the end of the 19th century, though the most consistent regeneration began only around 1930. Here also the larch is the dominant species with only rare stone pine individuals observed.

\subsection{Tree growth}

The plot chronologies (Fig. 2) start with a large inter-annual variability, due to the low number of samples included in the initial part of the curve and to the juvenile growth. Their length 


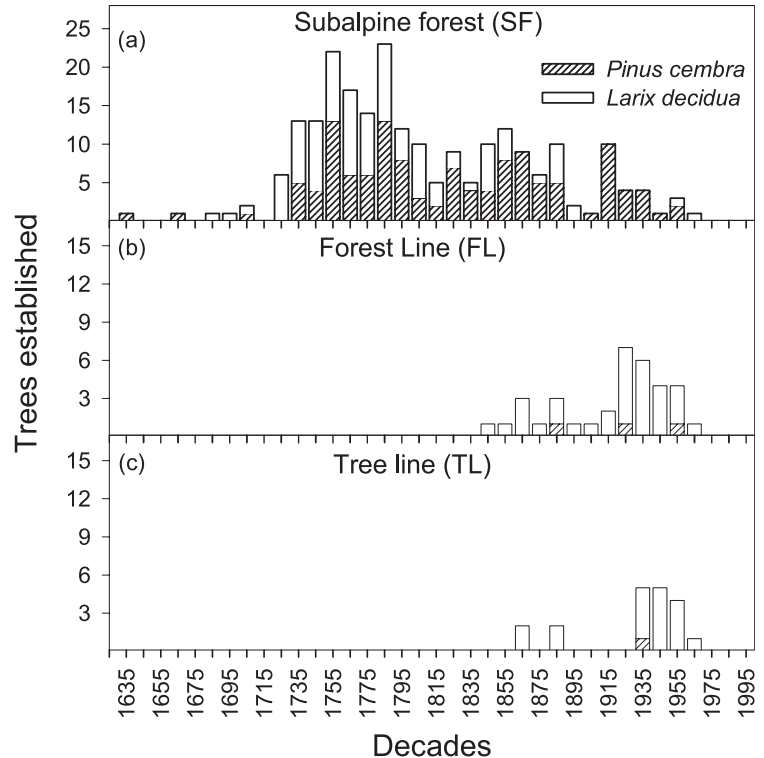

Figure 1. Age structure of Larix decidua and Pinus cembra, from (a) subalpine forest (SF, 1 ha), (b) forest-line (FL, 0.2 ha) and (c) treeline (TL, $0.2 \mathrm{ha}$ ).

is variable and decreasing with the altitude, so that the longest chronologies are obtained for SF (Tab. II, Fig. 2). The SF larch chronology differs from SF stone pine chronology in its periodic intense decreases in growth, related to outbreaks of Zeiraphera diniana Gn (Lepidoptera), [2,43,47,64]. The Rbar statistic is high for the stone pine chronology, as well as for the larch SF and FL chronologies, highlighting a high percentage of common signal in inter-annual growth variations between individuals (Tab. II). Conversely, the TL chronology shows a lower common signal. Indeed, for this chronology we obtained lower Rbar values, both for the entire period of analysis and in different specific time spans (Tab. III). In particular, the lowest values were obtained in the time spans centered around 1930, 1940, 1950 and 1960, increasing consistently in recent decades.

A correlation matrix between the three larch chronologies shows that the similarity between chronologies generally decreases by increasing the distance between plots (Tab. IV). However, if we consider the period 1927-1999, all of the larch plot chronologies are significantly correlated with each other, while in the sub-period 1927-1960 the correlation between the chronologies related to the extremes of the transect (SF and TL) is not statistically significant. From 1927 to the middle of 1960, the correlation coefficients between the SF and TL chronologies were low. However, in the middle of 1960, an abrupt increase in correlation was observed (Fig. 3). Indeed, from that moment up until recently, the growth response of the trees at the treeline was similar to the subalpine level, and the correlations between the two chronologies consequently increased significantly.

\subsection{Growth trends in dominant trees}

The low frequency chronologies obtained from the mean BAI chronology for the two species (centered by subtraction
Table II. Descriptive parameters of the standardized plot chronologies of Pinus cembra and Larix decidua. The mean sensitivity is the mean percentage change from each measured yearly ring value to the next and is a measure of the proportion of high-frequency variance [29]. The Rbar or mean inter-series correlation is a measure of the strength of the common growth signal within the chronology [66].

\begin{tabular}{lcccc}
\hline \multirow{2}{*}{ Chronology } & \multirow{2}{*}{ Pinus cembra } & \multicolumn{3}{c}{ Larix decidua } \\
\cline { 3 - 5 } & & SF & FL & TL \\
\hline First year & 1709 & 1718 & 1859 & 1881 \\
Last year & 1999 & 1999 & 2001 & 2001 \\
Chronology length (yr) & 291 & 282 & 143 & 121 \\
No. of trees & 85 & 48 & 21 & 31 \\
No. of cores & 85 & 49 & 33 & 44 \\
No. of rings & 14355 & 9512 & 2243 & 2523 \\
Mean sensitivity & 0.14 & 0.27 & 0.24 & 0.21 \\
Standard deviation & 0.20 & 0.36 & 0.33 & 0.33 \\
Rbar & 0.36 & 0.58 & 0.41 & 0.29 \\
\hline
\end{tabular}

Table III. Rbar statistic for the larch plot chronologies in different time span. The Rbar or mean inter-series correlation is a measure of the strength of the common growth signal within the chronology [66]. We adopted sections of 40-year window with an overlap of 30 years between adjacent windows. The analysis was performed on the period 1910-1999.

\begin{tabular}{lcccccc}
\hline $\begin{array}{l}\text { Chronologies/Rbar section } \\
\text { (40-years window) }\end{array}$ & 1930 & 1940 & 1950 & 1960 & 1970 & 1980 \\
\hline Subalpine forest (SF) & 0.60 & 0.54 & 0.65 & 0.72 & 0.71 & 0.75 \\
Forest line (FL) & 0.56 & 0.52 & 0.48 & 0.26 & 0.39 & 0.50 \\
Tree-line (TL) & 0.04 & 0.02 & 0.01 & 0.05 & 0.17 & 0.27 \\
\hline
\end{tabular}

Table IV. Correlation coefficients between the larch plot chronologies in different time span.

\begin{tabular}{lccccc}
\hline $1927-1999$ & FL & TL & $1927-1960$ & FL & TL \\
\hline SF & $0.73^{* *}$ & $0.39^{* *}$ & SF & $0.59^{* *}$ & 0.25 \\
TL & $0.56^{* *}$ & & TL & $0.39^{*}$ & \\
\hline
\end{tabular}

The symbols indicate the confidence level: ** 99\%; *95\%

of the mean) are plotted in Figure 4. The analysis was limited to the period 1785-1999 for both species in order to avoid periods in which the chronologies are not well replicated and characterized by juvenile years. The general trend is quite similar for both species and is characterized by an initial period of small BAIs, markedly under the mean value, until 1860 . In the following years, the BAIs values are higher and generally above the mean. The main difference between the two species is that the BAI variations in the stone pine are rather gradual, while in the larch very strong fluctuations can be observed along the entire curve. These oscillations are the results of periodic Zeiraphera diniana attacks.

\subsection{Growth trends in age-stratified data}

The analysis of BAIs in the cambial age classes was carried out on a total of 198 samples: 99 stone pines and 99 larches (Fig. 5). The number of samples within the decades in each 


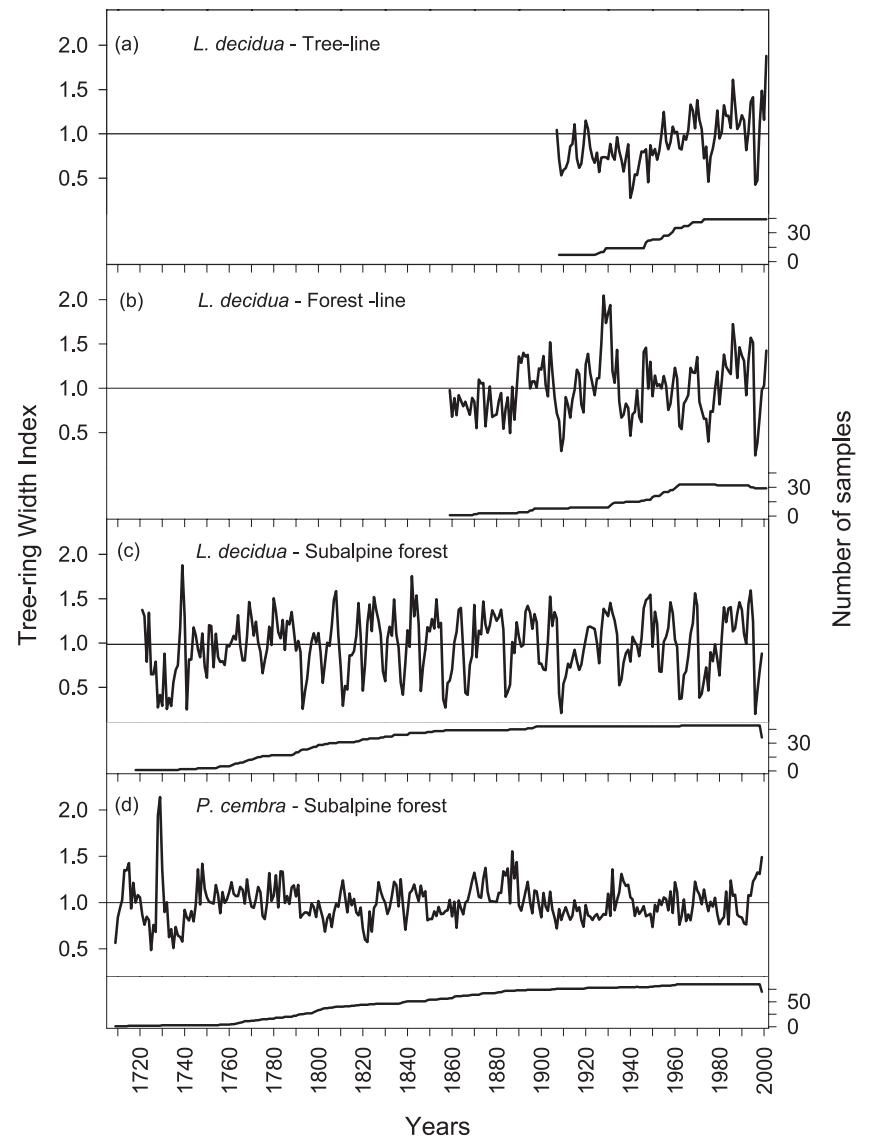

Figure 2. Standardized larch plot chronologies and relative sample depth (below) from (a) tree-line (TL), (b) forest-line (FL) and (c) subalpine forest (SF); (d) standardized stone pine chronology from subalpine forest (SF).

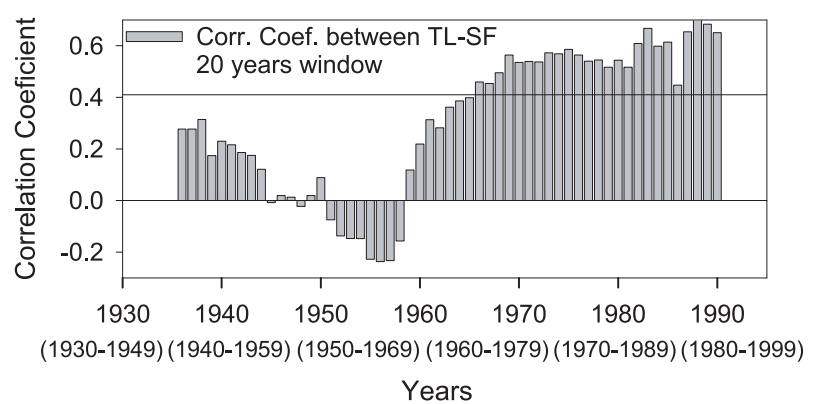

Figure 3. Correlation coefficient between TL and SF larch chronologies. Each bar represents the correlation coefficient between the two chronologies for 20 years window with an overlap of 19 years. The values of the correlations were assigned to the median year of the window. The horizontal line indicate the coefficient level (99\%).

age class obviously varied widely from a minimum of one to a maximum of 38 for the stone pine and 66 for the larch. Each point of the graph thus represents the mean of a very different sample size and has different statistical significance, a fact that must be taken into account when interpreting the results. The behavior of the two species was found to be very similar. Both showed a decline in growth over the last two centuries in

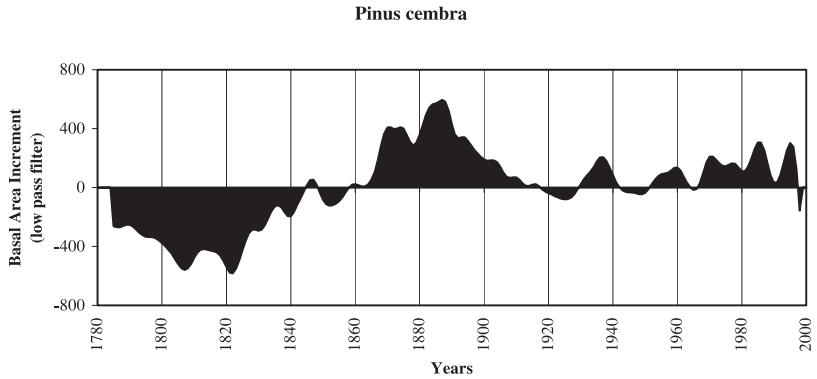

Larix decidua

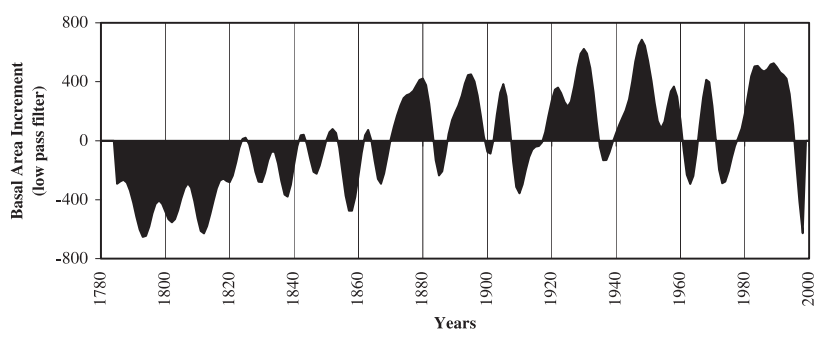

Figure 4. Low frequency chronologies of BAI for each species: data are filtered by a low pass filter and plotted centered by subtraction of the mean.

the lowest cambial age class (1-50), while in all the other age classes $(51-100,101-150,151-200)$, the trend reverses and growth actually increased within the time period considered.

\section{DISCUSSION}

According to the historical documents the studied area observed a reduction in grazing intensity in the first half of the 20th century. Heavy grazing followed by periods of moderate grazing is often associated with the onset of tree regeneration invasion of many sites $[14,53,58]$. In fact, moderate livestock grazing may facilitate tree establishment since few seedlings are trampled, bare mineral soil is exposed and competition from grasses is reduced [35]. According to Dunuviddie [14], these changes in meadow conditions enhance tree invasion for 20-25 years once intense grazing pressure is reduced. In the studied areas, these conditions were present at both the forestline and the treeline in the first decades of the 20th century, favoring the establishment of larch cohorts. These cohorts were browsed by the remaining domestic ungulates as evidenced by the narrow rings $[8,17,61]$ and by the lack of correlation between chronologies from TL (high domestic ungulate browsing) and SF (low or no domestic ungulate browsing) (Fig. 3). Since the decade of the 1960s there has been a new reduction of grazing intensity and in most of the trees established in the first decades of the 20th century the apex exceeded the browsing height and the trees were able to escape browsing $[37,60]$, with a beginning of a synchronous increment at the TL and at the FL as confirmed by a significant correlation between the TL and the SF chronologies (Fig. 3 and Tab. III). 

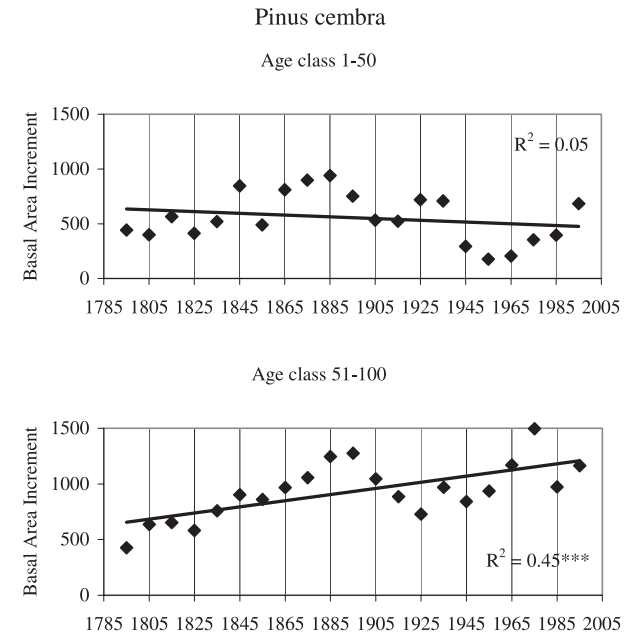

Age class 101-150

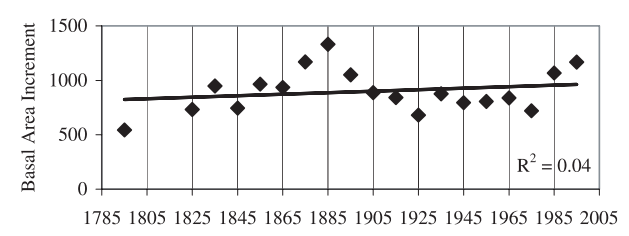

Age class 151-200

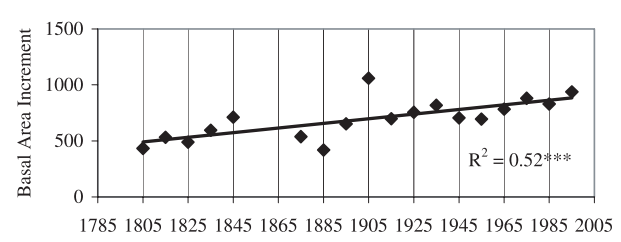

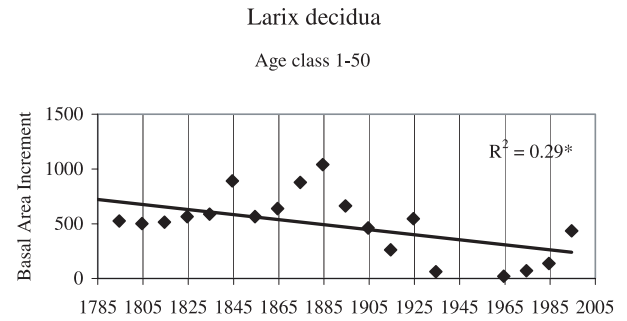

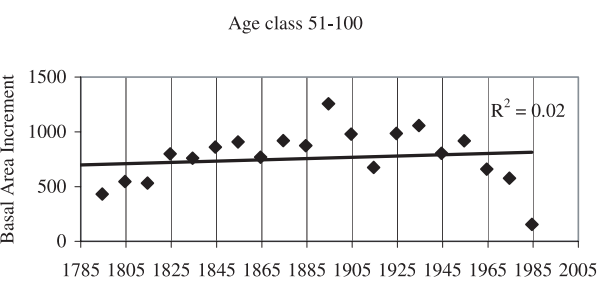

Age class $101-150$

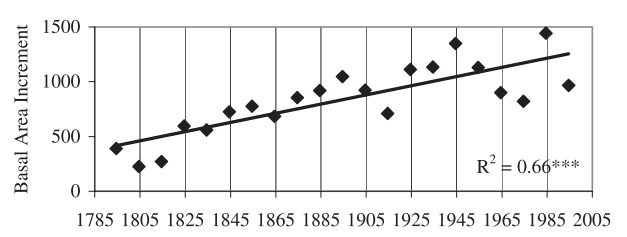

Age class 151-200

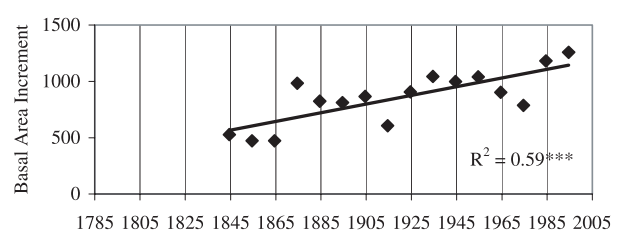

Figure 5. Decadal averages of BAI for different age classes of trees and for each species. Data are averaged decade by decade, separately, for the two species. Four age classes were considered: 1-50, 51-100, 101-150 and 151-200. The symbols indicate the confidence level: *** $99.9 \%$; $* * 99 \%$; * 95\%.
The growth of small trees $(\mathrm{h}<3 \mathrm{~m})$ at the treeline may respond differently to climate than taller trees $[19,33]$ but, in the study area, the growth change has been observed in the same time in individuals of different height $(0.5-3 \mathrm{~m})$ and of different age ( $>40$ years of age range) representing the occurrence of an "event" more than a "trend" [50]. Besides microclimate associated with microsite could control growth during the early stages of tree development $[32,48]$ but the study site has a very regular slope and morphology and microsite influence is low.

Moderate grazing of domestic ungulates allowed for the formation of a thick ground cover of grass and dwarf shrubs which prevented the establishment of light larch seeds that require mineral soil. As a consequence the stone pine, that was uprooted until the $1960 \mathrm{~s}$, became the favored species for establishment (as evidenced by the seedlings in Tab. I). Finally as far as the new tree establishment is concerned we have observed three distinct periods (Fig. 6): the oldest one (1850-1930) with sporadic larch regeneration, the intermediate (1930-1960) characterized by larch regeneration and the last one (1960-present) with stone pine regeneration.

Although the recent dynamics at the treeline have been influenced directly or indirectly by human activities, it is not possible to do likewise for the growth trends observed over a longer period. Indeed, the trends observed in the low frequency BAI chronologies of dominant trees throughout the entire area (Fig. 4) cannot be attributed to the effects of factors like grazing. In fact the individuals in the 100-, 150- and 200year age classes grow more rapidly in present times as compared to the previous two centuries (Fig. 5). The only age class which shows a slowing down in growth is that of trees younger than 50 years. The latter figure is consistent however with the evidence that current populations, being denser and more plentiful in regeneration, are subject to worse growing conditions, i.e. they receive less light because of the canopy cover and face fiercer competition at the ground and root level. In fact, under similar conditions in the Val Varaita similar results emerged [40], while in other areas of the Alps, various authors [4,42,48] have found growth rate increases that affected all age classes. However accurately interpreting trends in tree ring series and cambial age-stratified data is neither simple nor unequivocal, especially since the data is subject to numerous methodological biases $[27,40]$.

An analysis of all the data taken together in the present study argues in favor of the fact that the tree establishment, and more in general the forest dynamic, has been mainly controlled by human land-use (Fig. 6) and that the tree growth has been mainly climatically controlled (Figs. 4 and 5). Interpretation 


\begin{tabular}{|c|c|c|c|c|c|}
\hline & $\begin{array}{l}\text { Stone pine } \\
\text { uprooting }\end{array}$ & $\begin{array}{c}\text { Heavy density } \\
\text { ungulate grazing } \\
\text { (goat and sheeps) }\end{array}$ & $\begin{array}{l}\text { Moderate density } \\
\text { ungulate grazing } \\
\text { (sheeps and cows) }\end{array}$ & $\begin{array}{c}\text { Low density } \\
\text { ungulate grazing } \\
\text { (cows and sheeps) }\end{array}$ & Regeneration \\
\hline 1850 & & & & & \multirow{7}{*}{$\begin{array}{l}\text { No larch and stone pine } \\
\text { regeneration because of } \\
\text { heavy grazing; stone pine } \\
\text { anthropogenic seedling } \\
\text { removal }\end{array}$} \\
\hline 1860 & & & & & \\
\hline 1870 & & & & & \\
\hline 1880 & & & & & \\
\hline 1890 & & & & & \\
\hline 1900 & & & & & \\
\hline 1910 & & & & & \\
\hline 1920 & & & & & \multirow{4}{*}{$\begin{array}{l}\text { Larch regeneration: heavy } \\
\text { grazing followed by moderat } \\
\text { grazing; end of goat grazing; } \\
\text { stone pine anthropogenic } \\
\text { seedling removal }\end{array}$} \\
\hline 1930 & & & & & \\
\hline 1940 & & & & & \\
\hline 1950 & & & & & \\
\hline 1960 & & & & & \multirow{5}{*}{$\begin{array}{l}\text { Stone pine regeneration; } \\
\text { larch regeneration } \\
\text { prevented by ground cover; } \\
\text { end of the stone pine } \\
\text { anthropogenic seedling } \\
\text { removal }\end{array}$} \\
\hline 1970 & & & & & \\
\hline 1980 & & & & & \\
\hline 1990 & & & & & \\
\hline 2000 & & & & & \\
\hline
\end{tabular}

Figure 6. Tree establishment at the treeline and main land-use changes in the studied area. based on historical records must be tempered by an appreciation of the limitation inherent in the data [1]; besides, documentary records suffer of a "cultural" filtering that affects their availability, completeness, and reliability [51]. In spite of these limits, documentary records are a fundamental source of information that can be used to reconstruct the framework of historical human land use in a certain site, including key events that presumably implied consequences for the forest dynamic [38]. On the other hand documentary used as an independent data source in association with data from biological archives can be an important tool to validate hypotheses or add more information useful to have a good picture of the ecological process.

In the studied plots browsing of domestic ungulates has been the main driving force in controlling the forest dynamics for many centuries [6] and only in the recent decades the tree establishment has not been strongly affected by indirect (grazing) or direct (stone pine uprooting) human influences.

As far as the growth rate increment is concerned it is important to remember that the second half of the nineteenth century saw the end of the unfavorable climatic conditions of the Little Ice Age [22]. Other plausible causes of the growth rate increase could be climate warming or various anthropogenic factors, such as changes in nutrient fluxes due to air pollution and/or the fertilization effect of increasing $\mathrm{CO}_{2}$ $[4,18,20,21,24]$. Even if it is extremely difficult to demonstrate a clear cause-effect relationship between these factors and the increment in growth [66] this increment is of considerable importance since it points to an increased rate of sequestering of $\mathrm{CO}_{2}$ in the biosphere [28].

In the European Alps and, more in general, in Europe, where there are no ecosystems that are totally undisturbed by human activities, ecological studies must take into account both changing land use and changing climate $[11,49,56]$.
Acknowledgements: This study was funded by Italian MURST project "High altitude forests of the Alps and the Apennines: structure, growth limiting factors and future scenarios" and by the Istituto Italo Latino Americano (IILA). The manuscript was greatly benefited from comments by Ricardo Villalba and Mitch Aide.

\section{REFERENCES}

[1] Axelsson A.L., Östlund L., Hellberg E., Changes in mixed deciduous forest of boreal Sweden 1866-1999 based on interpretation of historical records, Landsc. Ecol. 17 (2002) 403-418.

[2] Baltensweiler W., Fischlin A., The larch budmoth in the Alps, in: Berryman A.A. (Ed.), Dynamics of forest insect populations: patterns, causes, implications, Plenum Press, New York, 1988, pp. 331-351.

[3] Becker M., Bilan de santé actuel et rétrospectif du sapin (Abies alba Mill.) dans les Vosges. Étude écologique et dendrochronologique, Ann. Sci. For. 44 (1987) 379-401.

[4] Briffa K.R., Increasing productivity of natural growth conifers in Europe over the last century, in: Bartholin T.S., Berglund B.E., Eckstein D., Schweingruber F.H. (Eds.), Tree rings and environment, Lunqua Report 34, 1992, pp. 64-71.

[5] Briffa K.R., Interpreting high-resolution proxy climate data. The example of dendroclimatology, in: von Storch H., Navarra A. (Eds.), Analysis of climate variability. Applications of statistical techniques, Springer, Berlin, 1995, pp. 77-94.

[6] Cairns D.M., Moen J., Herbivory influences tree lines, J. Ecol. 92 (2004) 1019-1024.

[7] Carcaillet C., Brun J.J., Changes in landscape structure in the northwestern Alps over the last 7000 years: lessons from soil charcoal, J. Veg. Sci. 11 (2000) 705-714.

[8] Chouinard A., Filion L., Detrimental effects of white-tailed deer browsing on balsam fir growth and recruitment in a second-growth stand on Anticosti Island, Québec, Ecoscience 8 (2001) 199-210.

[9] Cook E.R., A time series analysis approach to tree-ring standardisation, University of Arizona, Tucson, 1985. 
[10] Cuevas J.G., Tree recruitment at the Nothofagus pumilio alpine timberline in Tierra del Fuego, Chile, J. Ecol. 88 (2000) 840-855.

[11] Dirnböck T., Dullinger S., Grabherr G., A regional impact assessment of climate and land use change on alpine vegetation, $\mathrm{J}$ Biogeogr. 30 (2003) 401-417.

[12] Dotta A., Motta R., La gestione delle foreste comunali nel Consorzio Alta Valle Susa (TO), Sherwood 34 (1998) 13-20.

[13] Dullinger S., Dirnböck T., Grabherr G., Modelling climate changedriven treeline shifts: relative effects of temperature increase, dispersal and invasibility, J. Ecol. 92 (2004) 241-252.

[14] Dunwiddie P.W., Recent tree invasion of subalpine meadows in the Wind River Mountains, Wyoming, Arct. Alp. Res. 9 (1977) 393 399.

[15] Freléchoux F., Buttler A., Gillet F., Gobat J.M., Schweingruber F.H., Succession from bog pine (Pinus uncinata var. rotundata) to Norway spruce (Picea abies) stands in relation to anthropic factors in Les Saignolis bog, Jura Mountains, Switzerland, Ann. For. Sci. 60 (2003) 347-356.

[16] Fritts H., Tree-rings and climate, Academic Press, New York, 1976.

[17] Gill R.M.A., A review of damage by mammals in North Temperate Forests: 1. Deer, Forestry 65 (1992) 145-169.

[18] Grace J., Berniger F., Nagy L., Impacts of climate change on the tree line, Ann. Bot. 90 (2002) 537-544.

[19] Grace J., Norton D.A., Climate and growth of Pinus sylvestris at its upper altitudinal limit in Scotland: evidence from tree growth-rings, J. Ecol. 78 (1990) 601-610.

[20] Graumlich L.J., Subalpine tree growth, climate, and increasing $\mathrm{CO}_{2}$ : an assessment of recent growth trends, Ecology 72 (1991) $1-11$.

[21] Graybill D.A., Idso S.B., Detecting the aerial fertilization effect on atmospheric $\mathrm{CO}_{2}$ enrichment in tree-ring chronologies, Glob. Biogeochem. Cycles 7 (1993) 81-95.

[22] Grove J.M., The little ice age, Methuen Ed., London 1988.

[23] Guiot J., Goeury C., PPPBASE, a software for statistical analysis of palaeoecological and palaeoclimatological data, Dendrochronologia 14 (1996) 295-300.

[24] Guiot J., Nicault A., Rathgeber C., Edouard J.L., Guibal F., Pichard G., Till C., Last-millennium summer-temperature variations in western Europe based on proxy data, Holocene 15 (2005) 489-500.

[25] Hättenschwiler S., Körner C., Responses to recent climate warming of Pinus sylvestris and Pinus cembra within their montane transition zone in the Swiss Alps, J. Veg. Sci. 6 (1995) 357-368.

[26] Holmes R.L., Computer assisted quality control in tree-ring dating and measurement, Tree Ring Bull. 44 (1983) 69-75.

[27] Innes J.L., High-altitude and high-latitude tree growth in relation to past, present and future global climate change, Holocene 1 (1991) $168-173$.

[28] Janssens I.A., Freibauer A., Ciais P., Smith P., Nabuurs G.J., Folberth G., Schlamadinger B., Hutjes R.W.A., Ceulemans R., Schulze E.-D., Valentini R., Dolman A.J., Europe's terrestrial biosphere absorbs 7 to $12 \%$ of European anthropogenic $\mathrm{CO}_{2}$ emissions, Science 300 (2003) 1538-1542.

[29] Kaennel M., Schweingruber F.H., Multilingual glossary of Dendrochronology, Wsl/Fnp Birmensdorf, Paul Haupt, Berne, 1995.

[30] Kullman L., Rapid recent range-margin rise of tree and shrub species in the Swedish Scandes, J. Ecol. 90 (2002) 68-87.

[31] Le Roy Ladurie E., Histoire du climat depuis l'an mil, Flammarion, Paris, 1967.

[32] Li M.H., Yang J., Effects of elevation and microsite on growth of Pinus cembra in the subalpine zone of the Austrian Alps, Ann. For. Sci. 61 (2004) 319-325.
[33] Li M.H., Yang J., Kräuchi N., Growth responses of Picea abies and Larix decidua to elevation in subalpine areas of Tyrol, Austria, Can. J. For. Res. 33 (2003) 653-662.

[34] Löffler J., Lundberg A., Rössler O., Bräuning A., Jung G., Pape R., Wundram D., The alpine treeline under changing land use and changing climate: approach and preliminary results from continental Norway, Norw. J. Geogr. 58 (2004) 183-193.

[35] Mast J.N., Veblen T.T., Hodgson M.E., Tree invasion within a pine/grassland ecotone: an approach with historic aerial photography and GIS modelling, For. Ecol. Manage. 93 (1997) 181-194.

[36] Motta R., Impact of wild ungulates on forest regeneration and tree composition of mountain forests in the Western Italian Alps, For. Ecol. Manage. 88 (1996) 93-98.

[37] Motta R., Ungulate impact on rowan (Sorbus aucuparia L.) and Norway spruce (Picea abies (L.) Karst.) height structure in mountain forests in the Eastern Italian Alps, For. Ecol. Manage. 181 (2003) 139-150.

[38] Motta R., Edouard J.L., Stand structure and dynamics in a mixed and multilayered forest in the Upper Susa Valley (Piedmont, Italy), Can. J. For. Res. 35 (2005) 21-36.

[39] Motta R., Lingua E., Human impact on size, age and spatial structure in the mixed larch (Larix decidua Mill.) and Swiss stone pine (Pinus cembra L.) forest at Lago Perso (Western Italian Alps), Can. J. For. Res. 35 (2005) 1809-1820.

[40] Motta R., Nola P., Growth trends and dynamics in subalpine forest stands in the Varaita valley (Piedmont, Italy) and their relationships with human activities and global change, J. Veg. Sci. 12 (2001) 219230 .

[41] Motta R., Nola P., Piussi P., Long-term investigations in a strict forest reserve in the Eastern Italian Alps: spatio-temporal origin and development in two multi-layered sub-alpine stands, J. Ecol. 90 (2002) 495-507.

[42] Nicolussi K., Bortenschlager S., Körner C., Increase in tree-ring width in subalpine Pinus cembra from the central Alps that may be $\mathrm{CO}_{2}$-related, Trees 9 (1995) 181-189.

[43] Nola P., Morales M., Motta R., Villalba R., The role of larch budmoth (Zeiraphera diniana $\mathrm{Gn}$.) on forest succession in a larch (Larix decidua Mill.) and Swiss stone pine (Pinus cembra L.) stand in the Susa Valley (Piedmont, Italy), Trees 20 (2006) 371-382.

[44] Oberhuber W., Pagitz K., Nicolussi K., Subalpine tree growth on serpentine soil: a dendroecological analysis, Plant Ecol. 130 (1997) 213-221.

[45] Peterson D.L., Recent changes in the growth and establishment of subalpine conifers in Western North America, in: Beniston M. (Ed.), Mountain environments in changing climates, Routledge, London, 1994, pp. 234-243.

[46] Rochefort R.M., Peterson D.L., Temporal and spatial distribution of trees in subalpine meadows of Mount Rainier national park, Washington, USA, Arct. Alp. Res. 28 (1996) 52-59.

[47] Rolland C., Baltensweiler W., Petitcolas V., The potential for using Larix decidua ring widths in reconstructions of larch budmoth (Zeiraphera diniana) outbreak history: dendrochronological estimates compared with insect surveys, Trees 15 (2001) 414-424.

[48] Rolland C., Petitcolas V., Michalet R., Changes in radial tree growth for Picea abies, Larix decidua, Pinus cembra and Pinus uncinata near the alpine timberline since 1750, Trees 13 (1998) 40-53.

[49] Rozas V., Dendrochronology of pedunculate oak (Quercus robur L.) in an old-growth pollarded woodland in northern Spain: establishment patterns and the management history, Ann. For. Sci. 62 (2005) $13-22$.

[50] Schweingruber F.H., Tree Rings and Environment. Dendroecology, Swiss Federal Institute for Forest, Snow Landscape Research, Birmensdorf, Paul Haupt Verlag, Berne, 1996. 
[51] Swetnam T.W., Allen C.D., Betancourt J.L., Applied historical ecology: using the past to manage for the future, Ecol. Appl. 9 (1999) $1189-1206$.

[52] Szeicz J.M., MacDonald G.M., Recent white spruce dynamics at the subarctic alpine treeline of north-western Canada, J. Ecol. 83 (1995) 873-885.

[53] Taylor A.H., Tree invasion in meadows of Lassen Volcanic national park, California, Prof. Geogr. 42 (1990) 457-470.

[54] Tessier L., Chronologie de mélèzes des Alpes et petit âge glaciaire, Dendrochronologia 4 (1986) 97-113.

[55] Tessier L., de Beaulieu J.-L., Couteaux M., Edouard J.-L., Ponel P. Rolando C., Thinon M., Thomas A., Tobolski K., Holocene paleoenvironments at the timberline in the French Alps - a multidisciplinary approach, Boreas 22 (1993) 244-254.

[56] Theurillat J.P., Guisan A., Potential impact of climate change on vegetation in the European Alps: a review, Clim. Change 50 (2001) $77-109$.

[57] Tommervik H., Johansen B., Tombre I., Thannheiser D., Hogda K.A., Gaare E., Wielgolaski F.E., Vegetation changes in the Nordic mountain birch forest: the influence of grazing and climate change, Arct. Antarct. Alp. Res. 36 (2004) 323-332.

[58] Vale T.R., Tree invasion of montane meadows in Oregon, Am. Mid. Nat. 105 (1981) 61-69.
[59] Veblen T.T., Kitzberger T., Lara A., Disturbance and forest dynamics along a transect from Andean rain forest to Patagonian shrubland, J. Veg. Sci. 3 (1992) 507-520.

[60] Vila B., Keller T., Guibal F., Influence of browsing cessation on Picea sitchensis radial growth, Ann. For. Sci. 58 (2001) 853-859.

[61] Vila B., Torre F., Guibal F., Martin J.L., Growth change of young Picea sitchensis in response to deer browsing, For. Ecol. Manage. 180 (2003) 413-424

[62] Villalba R., Veblen T.T., Regional patterns of tree population age structures in northern Patagonia: climatic and disturbance influences, J. Ecol. 85 (1997) 113-124.

[63] Visser H., Note on relation between ring widths and basal area increments, For. Sci. 41 (1995) 297-304.

[64] Weber U.M., Dendroecological reconstruction and interpretation of larch budmoth (Zeiraphera diniana) outbreaks in two central alpine valleys of Switzerland from 1470-1990, Trees 11 (1997) 277-290.

[65] Welker J.M., Fahnestock J.T., Povirk K.L., Bilbrough C.J., Piper R.E., Alpine grassland $\mathrm{CO}_{2}$ exchange and nitrogen cycling: grazing history effects, Medicine Bow Range, Wyoming, USA, Arct. Antarct. Alp. Res. 36 (2004) 11-20.

[66] Wigley T.M.L., Jones P.D., Briffa K.R., Cross-dating methods in dendrochronology, J. Archaeol. Sci. 14 (1987) 51-64. 